\title{
The Structure of Design Processes: ideal and reality in Bruce Archer's 1968 doctoral thesis
}

\author{
Stephen Boyd Davis, ${ }^{a^{*}}$ Simone Gristwood ${ }^{\mathrm{b}}$ \\ ${ }^{a}$ Royal College of Art, UK \\ ${ }^{\mathrm{b}}$ Middlesex University, UK \\ *stephen.boyd-davis@rca.ac.uk
}

\begin{abstract}
The paper centres on a single document, the 1968 doctoral thesis of L Bruce Archer. It traces the author's earlier publications and the sources that informed and inspired his thinking, as a way of understanding the trajectory of his ideas and the motivations for his work at the Royal College of Art from 1962. Analysis of the thesis suggests that Archer's ambition for a rigorous "science of design" inspired by algorithmic approaches was increasingly threatened with disruption by his experience of large, complex design projects. His attempts to deal with this problem are shown to involve a particular interpretation of cybernetics. The paper ends with Archer's own retrospective view and a brief account of his dramatically changed opinions. Archer is located as both a theorist and someone intensely interested in the commercial world of industrial design.
\end{abstract}

Keywords: systematic method; science of design; cybernetics; embodiment

\section{Introduction}

This paper is centred on a single document, the 1968 doctoral thesis of $L$ Bruce Archer, entitled The Structure of Design Processes. At the Royal College of Art (RCA) for 27 years, Archer was a key figure in early Design Research and a driving force behind the attempt in the 1960s to be rigorous, and in particular "systematic", about the nature and practice of designing. He sought to establish a philosophy of design (Archer 1981a: 33), even a "science of design" (Archer 1968: Foreword), a phrase often associated with Simon's Sciences of the Artificial (Simon 1969) (Cross 2001). Essential to this science was Design Research, understood not only as the study of design's methods, but also of its ontology as a discipline and an activity. Archer's design philosophy also affected education in schools, through the Design Education Unit launched at the RCA in 1977 following a two-year study for the UK 
Government's Department of Education and Science. ${ }^{1}$ Archer was a vital contributor to the work of the Design Council, as a member of Council for ten years and of many of its committees. Partly through his work with Michael Farr, a design management entrepreneur and editor for many years of Design magazine, Archer engaged deeply with the commercial world. ${ }^{2}$ He lectured extensively to business audiences. His influence extended internationally through his work in Germany, the States, Canada, Turkey, India and elsewhere. Archer acknowledged that he learned more from such interactions than he might have realised at the time (Archer 1981b).

Archer wanted to grasp the nature of design as well as find better ways of designing. Of these two ambitions, he favoured the first. Christopher Frayling recalls Archer insisting, "I am not doing this to help practising designers. I am doing this to completely understand the design process" (Frayling 2013). His doctoral thesis exemplifies a tension between theory and practice that is still with us. Subtle features within it indicate the beginnings of a change in his thinking that later led to a radical reformation of his views, derived from his increasing real-world experience. J Christopher Jones, in an article for Design (Jones 1966), complains of "substantial but not always very practical publications", "both vague and dogmatic, [with] little reference to the work of practising designers." Archer's thinking about design was increasingly affected by practical design projects.

We will not rehearse here the many criticisms of "design methods" that have been made over the years, a rebellion initiated early on by Jones (1969) and Alexander (1971). These debates have been discussed by Cross (1993; 2007), Glanville (1999), Dorst (2003), Bayazit (2004), Margolin (2010), Pavitt (2012) and many others. Our topic instead is the changes generated within Archer's own thinking and his attempts to match his theories to the messy realities he encountered.

When Archer completed his thesis in 1968 he was 46 and had worked at the RCA since 1962, first in the School of Industrial Design as a researcher invited by Misha Black, then rising through a series of promotions to Research Professor of the newly named "Department of Design Research" (DDR) in 1972-73. Previously he had worked briefly at the Hochschule für Gestaltung Ulm with Horst Rittel among others (Krippendorff 2008). ${ }^{3}$ His own education had been in mechanical engineering at what is now City University. In an article for the RCA's Ark magazine (Archer 1972a), Archer said "he was a painter before being drafted into industry by the then Ministry of Labour." Serving in World War II from 1941 to 1944, he was discharged on medical grounds. By 1953 he had set up an engineering consultancy and was teaching evenings at the Central School of Art and Design; he was a full-time lecturer there by 1957 . He was writing articles for Design magazine, promoting what he called "a rational

\footnotetext{
${ }^{1}$ Archer describes himself as "a leading proponent of the concept of design studies as a fundamental component of the education of all children at secondary level" (Archer 1974).

${ }^{2}$ In the acknowledgements at the beginning of his thesis, Archer thanks Michael Farr who "gave the author many opportunities to put his theories to the test within the framework of the Michael Farr design management organisation" (Archer 1968).

${ }^{3}$ The Ulm Hochschule is characterized by Woodham (1997:180) as embracing a move away from intuition to method, from component to system, from product to process, and from the individual to an interdisciplinary design team as an appropriate means of solving problems, all features of Archer's later thinking.
} 
approach to design". It was from the Central School that he was invited by Tomás Maldonado to work at UIm. There Archer discovered two factions, the "mathematician/ scientists" (including theoreticians and applied psychologists) and the "designers". He inclined to the "mathematicians" camp (Lawrence 2001:43-44).

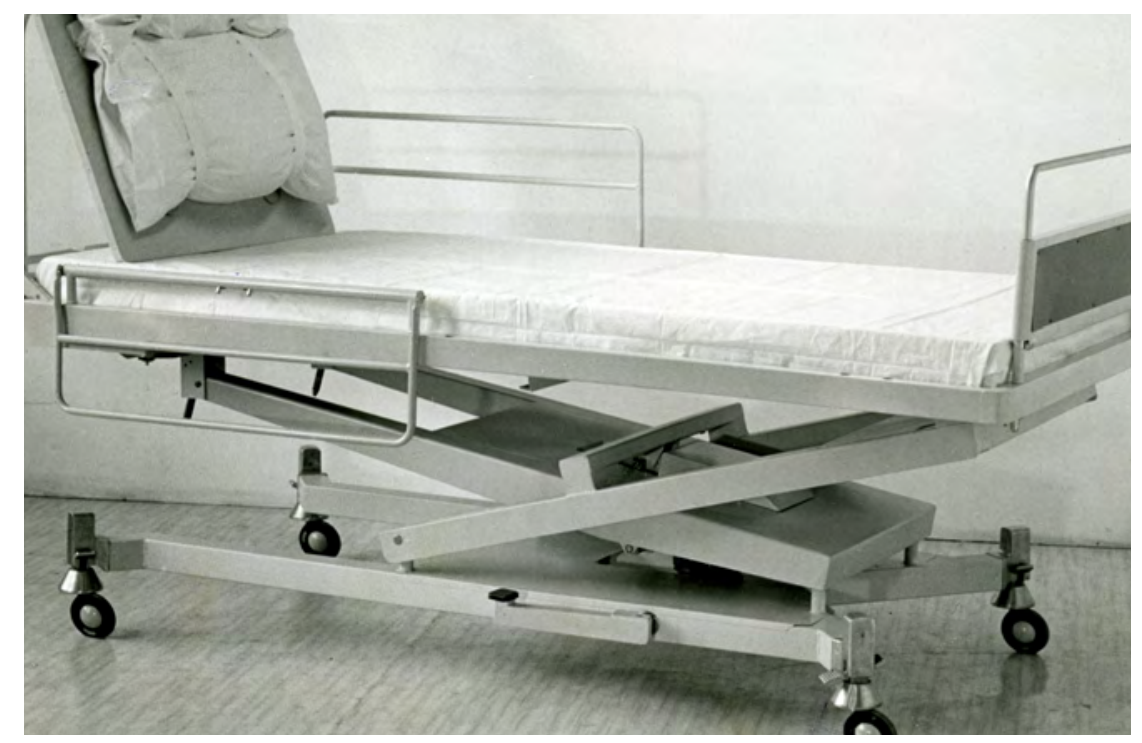

Figure 1 Bed height adjustment mechanism - a simple resolution of two opposing requirements. The King's Fund Hospital Bed designed by Kenneth Agnew at the Royal College of Art under Bruce Archer's leadership 1963-67. Photo: L. Bruce Archer Archive, RCA.

The Archer who arrived at the RCA therefore had a lot of experience of "real life", though less experience of large, complex design projects. That would soon change. Black had invited him to lead a research project on non-surgical hospital equipment funded by the Nuffield Foundation (Archer 2004). Archer saw the initial task as "the development of an organised body of knowledge that will assist manufacturers to design and hospital planners to select fixed and moveable equipment" (p.1). Four problems were chosen as the focus of the "organised body of knowledge", including the need for a standard design of hospital beds. There were over three hundred bed types in use, made in petty numbers by many companies. The Royal College of Nursing had reported the high incidence of permanent back injury among nurses due to the poor design of beds (p.2).

Probably because the outputs of this "organised body of knowledge" project appeared too theoretical and produced no prototype products, the first year's report to Nuffield was rejected and the follow-on three years of funding were denied. ${ }^{4}$ As Lawrence (2001:51) puts it, "In the design method which Archer was devising, a precise formulation of the design problem was essential, and this was what, in his view, the Report represented." This insistence on requirements capture prior to designing would be tested to the full as Archer gained more experience.

\footnotetext{
${ }^{4}$ Lawrence (2001) remarks that the notes of Archer's and his assistant Butter's deliberations "were couched in abstract terms and exhibited a preoccupation with methodology, with rigorous, often self-referential, definition and with stepwise progression."
} 
Following the rejection of the Report, Archer worked nights in an ice cream factory and for nothing at the RCA during the day (Archer 2004:3). Black found ways of keeping the rest of the team together, and recruited "one of his star graduates" Kenneth Agnew. Each of the four hospital projects was addressed, including the King's Fund hospital bed which "turned out to be a very big exercise" (ibid), and is exceptionally well documented by Lawrence (2001). Prevented by official policy from creating a single design, the team had to create a specification that manufacturers could respond to with their own solutions. ${ }^{5}$ Nevertheless, it was clear that the team would need to build real prototype beds and evaluate them against many criteria. The beds needed to be high to minimise injury to nurses, but low for the patients to get in and out: the solution was an adjustable-height bed. But straightforward resolutions like this were unusual. During the project, the team had to deal with intersecting issues of manufacturing, materials, healthcare, hands-on nursing, standards, safety, hospital management, patient satisfaction, industrial commerce, external relations, and institutional culture and politics at a number of levels. Such experience seems to have modified Archer's thinking and led him to question the simplicity of his original model of designing.

\section{The prehistory of the Archer thesis}

Archer's thesis was completed in 1968 (a remarkable year worldwide) but much of it had already appeared in print in a series of seven articles, "Systematic method for designers", roughly 27,000 words, published in Design magazine from April 1963 (Archer 1963-64). 6,7 Archer was a long-term contributor to the magazine founded by Alec Davis, its first editor, in 1949 and edited from 1952 by Michael Farr. "Systematic method" was published under the third editorship, that of John E Blake. The trajectory of Archer's thinking in these articles is not a simple one, but some key ideas emerge that later inform his work at the RCA. His first Design article (Archer 1954), published under Farr, argued the importance of both creative invention and profound technical knowledge in an industrial designer, a theme reprised a year later (Archer 1955). He then contributed a design analysis of a new typewriter (Archer 1955), this time highlighting poor British industrial innovation compared with competitors, a topic often revisited that highlights his interest in the commercial world. Four articles from 1956 (Archer 1956a) began a series again arguing against purely technical engineers working by rule of thumb: the industrial designer needed to be informed by both art and science. At this stage, Archer clearly sees the intuitive part of designing as preceding the scientific part (in italics he states "It is necessary that a hypothetical design shall first be laid down before

\footnotetext{
${ }^{5}$ Lawrence 2001 p.32. In 1967, a Report entitled The Design of Hospital Bedsteads was published by the King's Fund in London. The Report, which contained a specification for "a bedstead suitable for general purposes", was the result of a four year project which had cost in the region of $£ 35,000$.

${ }^{6}$ In current terminology, the thesis Archer presented might be considered a submission for doctorate by prior publication. The level of previously published material in it was surely unusual for the expectations and regulations of the time. To date no documents discussing this question have been found in the archives.

7 "Systematic Method" was highly valued by the readers of Design. A note in issue 38 (1965) p.73 states: "The unprecedented demand for this series of articles has made it necessary for DESIGN to publish them as a bound reprint, revised and extended by the author."
} 
analysis can begin" p.14) and explicitly says that design is not about "the evolution of forms by scientific methods".

In the second article of the series, Archer complains about the low proportion of "trained men engaged in scientific and technological work" compared to other nations (Archer 1956b:32). Design Research is envisaged as including the calculation of the bounding space of optimal solutions, based on data about requirements, materials and manufacturing methods - later a key part of Archer's thesis. Archer notes how "amateurism in management plays a very big part" in Britain's industrial failure (p.33). In the thesis this will lead him to think about management, game theory, and business decision processes. Still disenchanted with technicians who neither think creatively nor are up to speed with the state of their art, he is increasingly sanguine about science: "Herein lies the brightest hope for progress in design research and for the recovery of the art of designing from its present intimidated state" (p.35). The final series article (Archer and Zaczek 1956) calls again for more rigour in designing - from whatever discipline. Archer's next article (Archer 1957a) again calls for more science in design, but still does not necessarily require a science of design.

A series of articles with J. Beresford-Evans (later a visiting lecturer under Black and a key styling designer with him of diesel locomotives for British Rail (Jackson 2013: 63)) $)^{8}$ show Beresford-Evans focusing on the aesthetic aspects while Archer subjects cooking pans (Beresford-Evans and Archer 1957a), hand axes (Archer and Beresford-Evans 1957), and a free-standing fire (Beresford-Evans and Archer 1957b) to a series of tests. Archer continued these design analysis articles into the next decade. The 1957 articles emphasise the need to combine subjective and objective evaluation. There is a focus on qualities that matter to people, "almost atavistic" and "endowed with life" in the case of the domestic hearth (p.53). In "Electronic Instruments" Archer (1957b) rails at the assumption that a problem has only one solution (p.29). In "Honest Styling" (Archer 1957c) Archer makes the telling remark that the manufacturer has considered "not merely a machine, but a man/machine/work system" and notes with approval that its dial has "been redesigned close to principles enunciated by the Applied Psychology Research Unit, Cambridge, and was developed with the aid of advice obtained from the RAF Institute of Aviation Medicine, Farnborough."

On first studying the thesis, we thought we saw a simple transition: that Archer as a mechanical engineer was attempting to scientise design. But the preceding material has modified our view. Archer's original emphasis was on the need for creative design in engineering. He was arguing for rigour, not confined to scientific rigour, in industrial practice. Design decisions should be based where appropriate on objective data, and calculation used to identify the limits on optimal designs. No process would provide a single best solution. He assumed that the designer's vision preceded any application of logic.

\footnotetext{
${ }^{8}$ The business within which Black and Beresford-Evans worked was the Design Research Unit, a commercial consultancy having significant overlap with RCA academic staff but not to be confused with Archer's Department of Design Research. See Cotton 2010 for a history of the Design Research Unit 1942-1972.
} 
There is a strong emphasis on the commercial world, of survival and success in international markets, and the inadequacy of current management.

\section{Some influences on the Archer thesis}

By the time Archer wrote Systematic Method and the thesis, he was increasingly optimistic about a science of design. Now little is said about the need for creative input - most of it emphasises the power of a range of scientific disciplines. What led to this change? Titles in his bibliography are illuminating, including: Scientific method; optimising applied research decisions (Ackoff 1962); General systems theory, skeleton of a science (Boulding 1956); Prediction and optimal decision (Churchman 1961); Problem analysis by logical approach (Latham 1965); New product decisions: an analytical approach (Pessemier 1966). This was a period of high optimism about rational methods, systematic thinking and calculation in decision-making and execution. Operational Research (OR) and Organisation and Methods (O\&M) were seen to have yielded significant benefits in war (Kirby 2003) and administration. Archer is unequivocal: "A logical model of the design process is developed, and a terminology and notation is adopted, which is intended to be compatible with the neighbouring disciplines of management science and operational research. Many of the concepts and techniques presented are, indeed, derived from those disciplines" (Archer 1968: foreword).

Optimism about systematisation was closely allied to the adoption of computing. Agar (2003: Chapter 8 ) charts the relationship between "Treasury O\&M" and the computerisation of government work, the "government machine" metaphor instantiated in actual computational machinery. In 1968 computing was the key feature of Cybernetic Serendipity at the ICA and in 1969 Event 1, the first major public activity of the Computer Arts Society, was held at the RCA (Mason 2009). Many exhibitors were influenced by cybernetics, OR and Systems Theory (Bertalanffy's article "General System Theory" (1951) is cited in Archer's thesis and Bertalanffy"s book of that name came out in 1968). On the continent, New Tendencies in Zagreb included "Computer and Visual Research" from 1968, while computing featured in the Nuremberg and Venice biennales from 1969 and 1970. Max Bense, whose pursuit of "rational aesthetics" involved him in one of the first computer arts exhibitions in Stuttgart in 1965, taught at UIm in the 1950s and "was the intellectual backbone of the school at that time" according to Krippendorf (2008:57).

For the 1962 Conference on Design Methods, Jones opened his paper with the words, "A trend towards more logical and systematic methods of design has been evident throughout the 1950s. In many cases they have appeared as the result of new technical developments such as computers, automatic controls and systems" (Jones 1963). Next year Archer wrote, "the logic by which computers work, and the clarity and fullness of expression which is necessary to prepare a real-world problem for computing, are valuable indicators of the sort 
of logic which might work even without a computer" (Archer 1963). ${ }^{9}$ A report on government computing in 1956 had explained that all computing systems include input of data and instructions, storage, control, operations for calculation or processing of data, and output (National Physical Laboratory 1956: 3). This linear approach was in many ways just what appealed to Archer, Jones and many others. They were stimulated by the need to be explicit about the problem they were trying to solve and by the need for data at the outset. But alternative models would also claim Archer's attention, as discussed below.

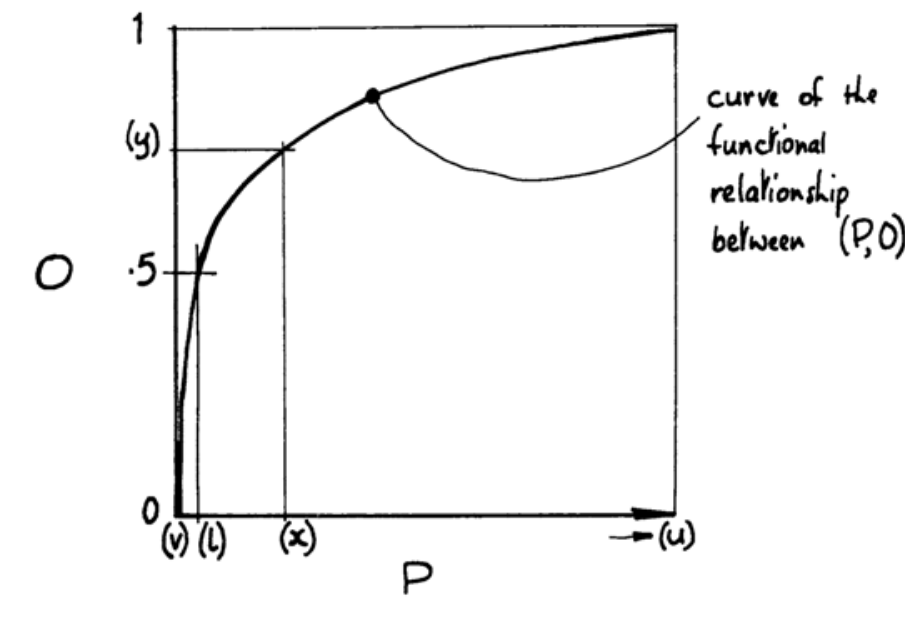

$$
\begin{aligned}
& \text { Example of a relationship between an objectwe and a property } \\
& \text { laking the form: } \\
& \qquad O(y)=1-\frac{P(L)}{2 P(x)}
\end{aligned}
$$

Figure 2 Figure 2.4 from Archer's doctoral thesis illustrating the case where "a product may be required to be as profitable as possible, with a low limit of profitability, but no high limit" (Archer 1968: section 2.10).

\section{Archer's thesis document}

The Archer thesis is divided into chapters on definition of design, the nature of the act of designing, the systematic model, the operational model, the design programme, the logic of design procedure, design factors, the problem of aesthetics, the problem of imperfect information, techniques in problem solving, and finally a summary and conclusions. It comprises about 36,000 typewritten words, 80 pages of diagrams and 90 endnotes. The argument proceeds by introducing a simple model of the design process and refining it chapter by chapter. The diagrams are significant. Many are graphs (Figure 2). Many resemble algorithmic flow charts (Figure 3). Others show the relation between such models

\footnotetext{
${ }^{9}$ At a practical level as well as metaphorically the DDR under Archer pioneered the uses of computing in design. In 1964 it was stated that, "In recent years Mr Archer has devoted himself to the development of a system of logic for the solution of design problems and has become deeply involved in the application of computer techniques. At the moment he is engaged in applying these techniques" (Granada Television 1964:6). George Mallen and Patrick Purcell were key figures within the DDR in this development, as was John Lansdown from his position in the Science Research Council. See Gristwood and Boyd Davis (2014); Boyd Davis and Gristwood (2015; 2016).
} 
and the real world (Figure 4), illustrating Archer's interest in connecting his schemata to reality.

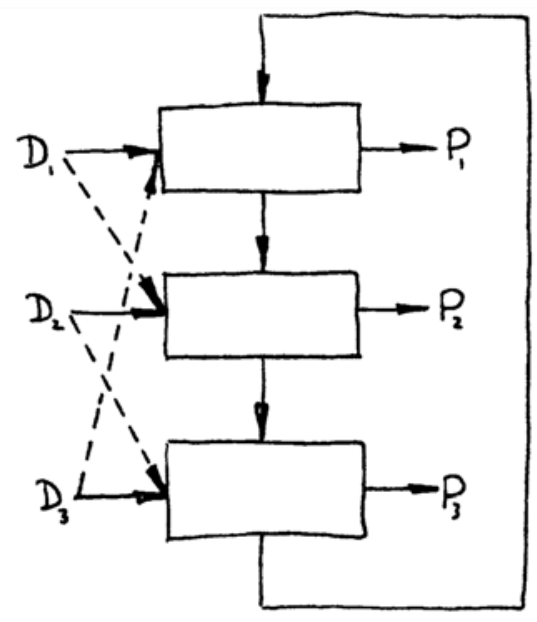

Sometimes a complex system will form a clored loop, each subsystem controlled by an oulput from another subsystem in the complex

Figure 3 Figure 4.5 from Archer's doctoral thesis illustrating the case where "a system of systems may form a closed loop, with every subsystem depending on inputs from another subsystem" (Archer 1968: section 4.9).

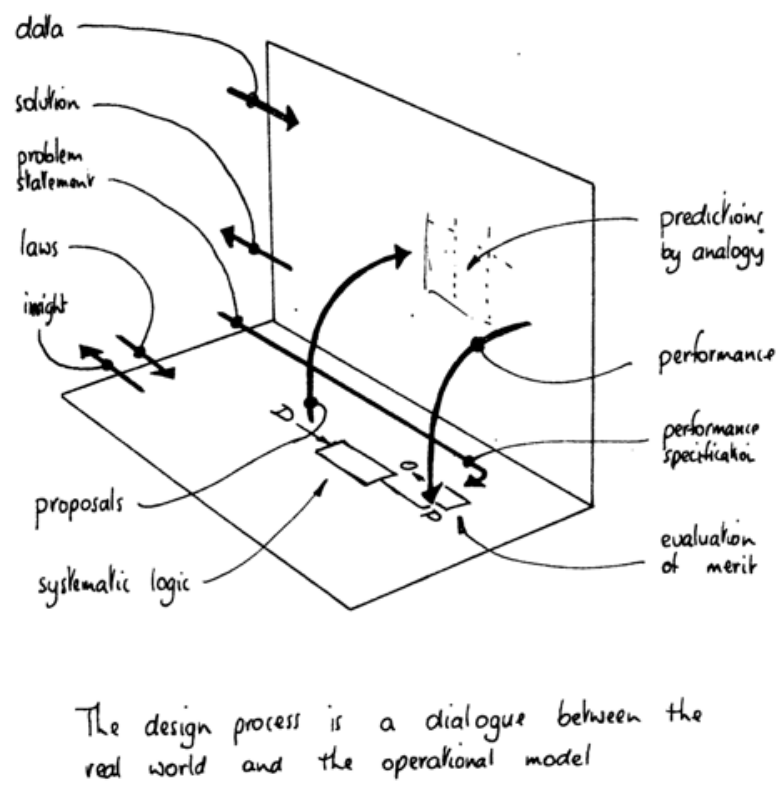

Figure 4 Figure 4.6 from Archer's doctoral thesis illustrating how "the design process is thus a dialogue between the real-world and the operational model" (Archer 1968: section 4.10). 


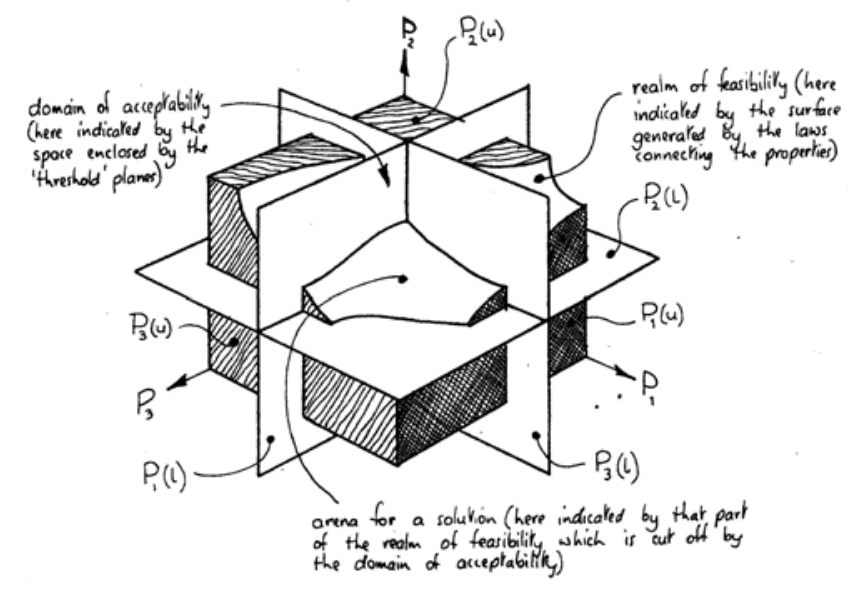

Figure 5 Figure 2.18 from Archer's doctoral thesis illustrating how "the interdependence of the curves of feasible mutual states will constitute an n-dimensional hypersurface or realm of feasibility. An important pre-requisite for an ultimate solution is that at least a portion of the realm of feasibility should intersect the domain of acceptability, producing an arena within which a solution must be found" (Archer 1968: section 2.27).

An important feature is the calculation of the solution space within which the final design must lie (Figure 5). To calculate this, clearly the requirements and constraints must be known in advance. Archer tended to believe at this stage that the design process began with defining the brief, establishing the requirements and giving them appropriate weights, securing the necessary data and then actually designing. The requirements stand outside the iterative cycle. His diagram (Figure 6), appearing in similar form in several works in the 1960 s, clearly shows the brief as outside and preceding the design process proper. Data analysis, synthesis and development are all allowed to retrospectively alter data collection (presumably as the need for new facts becomes apparent) but none of these alters the brief and therefore the requirements.

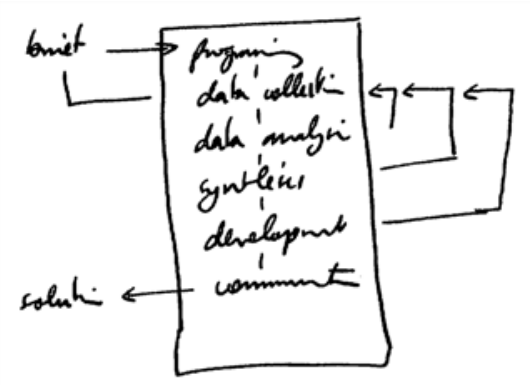

Figure 6 "Simplified checklist" from Archer's handwritten notes entitled "Lecture for London College of Furniture 25 Feb 1965 Systematic method 1 - Introduction" from L Bruce Archer Archives, $R C A$, London: box 2.1.2. The brief precedes and lies outside the design cycle.

Archer had a very particular view of designing as being prior to making: "A key element in the act of designing is the formation of a prescription or model for a finished work in advance of its embodiment." Thus a sculptor working directly with his or her material is not designing, but "when a sculptor produces a cartoon for his proposed work, only then he can 
be said to be designing it" (Archer 1963 Part Two: 70). ${ }^{10}$ But this ideal model, in which requirements are finalised prior to designing, which then proceeds in an orderly manner, shows subtle signs of disturbance in the thesis. Surely the fact that Archer had managed and studied the horribly complex Hospital Bed and other live projects, rather than simply observing designing at a distance, must have made him more aware of the messiness - and the embodied nature - of real world design?

\section{The model disrupted}

There are a number of disturbances to the systematic model. These include complexity, the need to revisit the brief and requirements, and the problem of securing good data.

\subsection{Complexity}

Archer always acknowledged that there are multiple solutions to design problems. Figure 5 and its associated thesis text (Archer 1968: section 2.27) make clear that multiple solutions may occupy the spaces between the bounding surfaces of feasibility and acceptability. Yet one key reason to be pessimistic about any systematic method is the interdependence of factors. Fixing one problem opens another, and typically unforeseen consequences occur, problems of complexity characteristic of socio-technical systems (Johnson 2010:120) - such as hospital beds. Even exhaustive computation may not do the trick: "to derive a trend which would point to an ideal solution, is only just becoming feasible and yet might never be attainable because of the large number of variable factors which are not always interdependent" (Archer 1956a:14). ${ }^{11}$ Archer's colleague at Ulm, Horst Rittel, memorably characterised these as "wicked problems" in dialogue with C West Churchman at just the time Archer was finalising his thesis. Both authors feature in the thesis (Churchman 1961; Rittel 1965), and he explicitly notes the significance of dependence (Archer 1968: endnote 60). A characteristic passage in the Rittel chapter cited by Archer could be a description of problems like the hospital bed: "...it can be expected that the exchange of associations between several persons is likely to raise this threshold since each association acts as a new stimulus on the other persons. In this manner not only $C$ is increased but also the diversity of the associations produced. This diversity is greatest when the individual reservoirs of associations overlap least (i.e. they are specialists from widely different fields)" (Rittel 1965: 209-210).

\subsection{Requirements in contention}

Despite diagrams like Figure 6 that appear to show the brief lying outside and prior to the design process, Archer actually acknowledges at several points that the requirements which the designers thought they were working to may be subject to revision at almost any point.

\footnotetext{
${ }^{10}$ This leads Archer to the odd contention that a couturier is designing even when making a garment on the stand - but only provided this is not the finished item but a prototype for a garment that is going to be made subsequently (Archer 1963 Part Two: 70 ).

${ }^{11}$ Given the context and flow of argument at this point, it seems possible that Archer meant to end this sentence "are not always independent". In any case it is clear that he believes there is significant interdependence between factors.
} 
As Rittel put it later: "...the irritating thing is that, depending on the state of solution, the next question for additional information is unique and dependent on the state of solution you have already reached" (Rittel 1972:392). In Archer's words, "During the course of the problem solving activity new objectives may tend to form and reform" (Archer 1968: 2.29); "The complete set of objectives is only rarely definable at the beginning of the project. Most of them emerge by mutual consent as the project progresses" (Archer 1968: 6:15). He seems comfortable with this, even though we might consider that it undermines some key aspects of his system: "It is open to the arbiter or arbiters in a problem to manipulate the importance ratings in any way they wish, and to revise their ratings at any stage they wish, so as to represent their true aims and interests as the consequences of their decisions emerge, or fresh information becomes available." (Archer 1968: 3.30). And these are not just minor refinements: "any effective design procedure must therefore permit radical reappraisal of the problem at any stage." (Archer 1968: 6:17 emphasis added). Again the real-world complexities of design projects seem to have had a progressive influence on Archer's thinking, but without yet undermining his faith in the system.

\subsection{Lack of good data}

For Archer, the designer or engineer must work with the best possible information rather than relying on intuition or custom and practice. OR and O\&M had both promoted the provision of adequate data in order to be effective. In ergonomics, Jones had been advocating the use of strong data for more than a decade (Jones 1954). Dreyfuss' influential anthropometric files had been published repeatedly in the preceding ten years (Dreyfuss 1959). Yet in key areas that Archer considered essential to design, including aesthetics, he acknowledges the lack of good data. A work cited frequently in the thesis confronts the twin problems of interdependence and uncertainty (Tavistock Institute 1966). Archer bemoans the lack of "a corpus of knowledge or a set of techniques capable of providing rational aesthetic decisions" (Archer 1968: 8:17). This for him is a lack of good information, not a fundamental difficulty in processing and using qualitative data: "it should be possible to collect data and to carry out analyses of trends and probabilities, using techniques well developed in the natural and social sciences" (Archer 1968: 8:16); "The principal distinction between phenomena from the operational point of view is therefore not in their 'qualitative v. quantitative' character but in their 'known v. not known' character (Archer 1968: 9.4). There are problems of both availability and quality: "the data is difficult to find, and when found it very often contains redundancies, errors and omissions" (Archer 1968: 9.9). This arises from the very nature of design problems, dealing as they do with so many kinds of criteria (Archer 1968: 9.10). Later, Archer would present an important paper precisely on computing with qualitative data (Archer 1972b. See Gristwood and Boyd Davis 2014: 622).

\section{Games and cybernetics}

We have discussed Archer's inspiration in OR, O\&M, computation and systematic decision making. How did he deal with the kinds of problems we have just highlighted, which 
threatened to disrupt such models? Two key areas of his bibliography are concerned with game theory and with cybernetics, disciplines that both deal with ongoing, unpredictable, dynamic systems and with emergent properties. They are thus quite distinct from the pipeline model that at first sight seems fundamental to Archer's system and is the basis of simple OR and O\&M. ${ }^{12}$ As Pickering (2002) puts it, "cybernetics grabs on to the world differently from the classical sciences. While the latter seek to pin the world down in timeless representations, cybernetics directly thematizes the unpredictable liveliness of the world, and processes of open-ended becoming." Pickering distinguishes cerebral, representational American cybernetics from the embedded and embodied UK cybernetics created by Ashby, Beer and Pask, all of whose works appear in the Archer bibliography (Ashby 1957; Beer 1959; Pask 1961). Cybernetics attempts to break the distinction between biological and artificial systems, between brains and bodies, entities and their environments, and "cuts across the entrenched departments of natural science" (Pask 1961: 11). Cybernetics offers Archer a way to envisage how "the design process is thus a dialogue between the real-world and the operational model" (Archer 1968: 4:10) (Figure 4).

Two cyberneticians in particular are relevant to the problems of complexity and uncertainty - Ashby and Pask. Ashby notes how complexity had been avoided traditionally: not until the 1920s "did it become clearly recognised that there are complex systems that just do not allow the varying of only one factor at a time-they are so dynamic and interconnected that the alteration of one factor immediately acts as cause to evoke alterations in others, perhaps in a great many others" (Ashby 1957:5). Ashby and Pask can often be read as though describing complex multi-stakeholder design projects: "There is first a set of disturbances $D$, that start in the world outside the organism, often far from it, and that threaten, if the regulator $R$ does nothing, to drive the essential variables $E$ outside their proper range of values" (Ashby 1957:209). Ashby on emergent properties: "Often, however, the knowledge is not, for whatever reason, complete. Then the prediction has to be undertaken on incomplete knowledge, and may prove mistaken" (Ashby 1957: 111). Pask also toys with situations "where the objective is not obvious at the outset and only becomes so when some tentative knowledge has been gained" (Pask 1961: 19). "Uncertainty stems from ourselves and our contact with the World" (p.21). Perhaps this remark of Pask's appealed to Archer after all the tribulations of complex practical projects: "Cybernetics offers a scientific approach to the cussedness of organisms, suggests how their behaviours can be catalysed and the mystique and rule of thumb banished" (p.110).

\section{Looking back}

Several of the works that Archer cites exploit the notion of a black box (Ashby 1957, Beer 1959, Duckworth 1962, Pask 1961), the cyberneticians in particular celebrating the idea. Archer does not echo their admiration, perhaps annoyed that designers themselves are so

\footnotetext{
12 One of the information management sources in Archer's bibliography is unusual in offering the remark "A sophisticated total system would even include its own arrangements for adjusting (redesigning) itself to meet the needs of a changing environment" (McDonough 1963: 242).
} 
unfathomable: "meanwhile, the only effective 'black box' is the sensibility of a discerning and creative designer." He wanted to open the black box of designing and discover what was inside. Though his "structure" and his "systematic method" look very like algorithms for designing, in the end he was, above all, interested to understand what designing is. Mclntyre (1995) suggests that Archer's thinking continued unchanged, yet this is clearly not the case. Years later he felt that he had "wasted a lot of time trying to bend the methods of operational research and management techniques to design purposes" (Archer 1979). He now offered a dramatically different approach: humanities, science and design as equal points of a triad of disciplines. Archer announced that "there exists an under-recognised but definable third area of human knowing, additional to numeracy and literacy" (1978: foreword, emphasis added). Ten years after 1968, the "year of revolutions", it was "Time for a Revolution in Art and Design Education" (Archer 1978: title), and Archer, through the Design Education Unit led by Ken Baynes, would set about creating it (Green and Steers 2006).

Given Archer's own negative re-assessment of his systematic method, there is a risk of underestimating what Archer achieved. The year before he died (Archer 2004), he himself felt that "we had at least established that work study, systems analysis and ergonomics were proper tools for the industrial designer's trade." He was surely right about the need for design to be informed by the latest knowledge and for custom and practice to be always challengeable by new data. He championed research into how prototype products were actually used in real contexts. How many objects and systems would be better designed if only his rigorous questioning approach were more common, even now? Though he did not foresee just how bad the decline in UK industrial innovation would become, he diagnosed its causes.

When Jocelyn Stevens became Rector at the RCA in 1984, he closed the Department of Design Research. For George Mallen (2011), the effect was to "almost annihilate any intellectual activity in the College." Stevens kept Archer on while sacking all his staff. "It broke Bruce's heart" in the opinion of Christopher Frayling (2013). Archer's insistence that he was not trying to help practising designers almost certainly told against him - he paid the price for such honesty. The other departments stood by and watched the Department close. At Senate, "nobody said a word. They were just relieved it wasn't them" (Frayling 2013). 
6 The logic of design yrocedure

6.1 Two more concepts must be introduced before the structure of the desim act as formulated in this thesis can be presented as a whole. These are, firstly, the concept of decomposition, applied to the rastructuring of the network of subproblems of which the overall design problem is composed; and secondly, the concept of the theory of games, applied to the relationships between the participants in a product development project.

6.2 It has already been argued (paras. 3.7 and 5.12) that the systems comprising a product developinent problem may be interconnected. Indeed, it is clear that if a system or mroup of systems is neither affected by the decisions made in another (or the remaining) systems in the problem field nor affects their outcomes, it can be handled as a completely separate problem (fig, 6.1). For example, in a manufacturing company's rationaliaation progronme, the redesign of certain of the company's products may 30 hand in hand with the rediaposition of the sales force. Botin lezs of the programme may be desirable in the realisation of the overall set of objectives. However, it is posgible that in the circumstances of the project none of the decisions available within the design Iesource can have any effect upon the disposition of the sales force, and that none of the decisions available within the sales reorganization resource can have any effect upon product design. They can thus be handled as two sevarate problems.

This paper is concerned in general only with single problems, and in particular with thet class of problem which is concerned with the design of artifacts.

6.3 It has been shown (section 3) that according to the conventions adopted two gocl-decision systems are connected when either their respective decision variables or their respective output properties are identical or dependent. In either event a decision affecting one vili automatically affect the other, and the outcome of one vill relate to the outcome of the other (fig. 6.2). The two systems taken togethor constitute a larger system.

6.4 Two such comperma systems, if linked, form $a$

larger system, and two of these form a yet

larger syster, and so on in a hierarchy until the thole problem is embraced (fig, 6.3). In a oingle problem field at least ono hierarchy is bound to be assignable. If, in a particular instance, it proves to be iropossible to embrace all the aystems in one hierarchy, then there must be more than one independent problem present.

Figure 6 An example page from Archer's doctoral thesis. Section 6 introduces "The logic of design procedure" and begins by highlighting two topics: 1. the piecewise procedural approach of "decomposition" (an approach also fundamental to computer algorithm design); 2. the theory of games - indicating Archer's increasing acknowledgement of the complex and emergent nature of larger design projects. 


\section{A note on the thesis document}

The thesis was published in photocopied form in 1969 by the U.S. Department of Commerce National Technical Information Service, and was republished, according to Archer (1971), in Japanese in 1970 and in French by the Ministère des Affaires Culturelles in 1971. The photocopy is from an original bearing many hand-written corrections and amendments. Not least, the title has been altered, from "The Structure of the Design Process" to "The Structure of Design Processes". The chapter title "The problem of aesthetics" has added underlining and a question mark - the corresponding section of "Systematic Method" in Design issue 172 was called "The meaning of aesthetics" - and there are many other alterations. Intriguingly, the very last page has an acknowledgement to the book designer Brian Grimbly, which suggests that the thesis was at the same time a book manuscript. A later archived letter from Terry Bishop (1980), editor at Design Council Books, begins:

“Dear Professor Archer

\section{A PHILOSOPHY FOR DESIGN}

I'm sure you remember our joint intention to produce a book based on your RCA lectures under this title.

As your text is now long overdue, however, I wonder whether you want to proceed with this project."

We can assume that this is not a book based on the thesis, given how much Archer's thinking had changed in the twelve years since its completion, yet it is intriguing to wonder at the contents of the book that never appeared and how it would have reflected the profound shifts in Archer's thinking.

Acknowledgements: The authors are deeply grateful for interviews, providing essential insights, with Kenneth Agnew, Miranda Archer, Ken Baynes, Sir Christopher Frayling, Ghislaine Lawrence, George Mallen, Phil Roberts and Doug Tomkin; also to Neil Parkinson, RCA archivist, and to the staff of the Design Archive at University of Brighton and the DDR Archive at the V\&A. They also gratefully acknowledge the valuable advice of the anonymous DRS reviewers. Dr Simone Gristwood's research has been partly funded by the Paul Mellon Centre for Studies in British Art and the RCA.

\section{References}

Ackoff, Russell L. (1962) Scientific Method; optimising applied research decisions. Wiley.

Agar, Jon. (2003) The Government Machine: a revolutionary history of the computer. MIT Press Cambridge MA.

Alexander, Christopher. (1971) State of the Art in Design Methodology: Interview with C. Alexander DMG [Design Methods Group] Newsletter 5(3) (March 1971): 3-7.

Archer, L. Bruce. (1954) Artist Versus Engineer. Design 67. July 1954. 13-16.

Archer, L. Bruce. (1954) Art Training for Engineering Draughtsmen. Design 78. June 1955. 14-17.

Archer, L. Bruce. (1955) A New British Typewriter. Design 79. July 1955. 26-29.

Archer, L. Bruce. (1956a) Intuition versus Mathematics. Design 90. June 1956. 12-19.

Archer, L. Bruce. (1956b) Design Research: design and stress analysis 2. Design 91. July 1956. 
Archer, L. Bruce. (1956c) Analytical Methods for Product Designing [design and stress analysis 3. Design 93. September 1956. 29-33.

Archer, L. Bruce and Bohdan J. Zaczek. (1956) Design 96. December 1956 42-46 Photo-Elasticity for the Product Designer: design and stress analysis 4.

Archer, L. Bruce. (1957a) Theory into Practice. Design 101. May 1957. 18-23.

Archer, L. Bruce. (1957b) Electronic Instruments. Design 107. November 1957. 29-33.

Archer, L. Bruce. (1957c) Honest Styling. Design 108. December. 36-39.

Archer, L. Bruce. (1963) Lecture to Architectural Association School of Architecture. Unpublished typewritten notes. L Bruce Archer Archive, Royal College of Art.

Archer, L. Bruce. (1963-64) Systematic method for designers: Part one: Aesthetics and logic (Design 172. April 1963. 46-49); Part two: Design and system (Design 174. June 1963. 70-74); Part three: getting the brief (Design 176. August 1963. 52-57); Part four: Examining the evidence (Design 179. November 1963. 68-72); Part five : the creative leap (Design 181. January 1964. 50-52); Part six: The donkey work (Design 185. May 1964. 60-63); Part seven: The final steps (Design 188. August 1964. 56-59). All these issues of the magazine were edited by John E. Blake.

Archer, L. Bruce. (1965) Handwritten notes entitled 'Lecture for London College of Furniture 25 Feb 1965 Systematic method 1 - Introduction' from L Bruce Archer Archives, RCA, London: box 2.1.2.

Archer, L. Bruce. (1968) The structure of design processes. Thesis (Ph.D.) Royal College of Art, London, 1968. Shelfmark: Document Supply DRT 484530. Available on Ethos: http://ethos.bl.uk/OrderDetails.do?uin=uk.bl.ethos. 484530

Archer, L. Bruce. (1971) Technological innovation - a methodology. Frimley, Surrey: Inforlink Ltd for Science Policy Foundation Ltd.

Archer, L. Bruce. (1972a) 'Why do I go on working in this place?' Ark No.50. London: Royal College of Art.

Archer, L. Bruce. (1972b) Computers, design theory and the handling of the qualitative. Proc. International Conference on Computers in Architecture, University of York, 20-22 September 1972.

Archer, L. Bruce. (1974) Letter to Professor Charles Wallschlaeger of Ohio State University, including a draft recommendation for Wallschlaeger to write in support of Archer's distinguished visiting professorship. L. Bruce Archer Archive, Royal College of Art.

Archer, L. Bruce. (1974) Design awareness and planned creativity in industry. Jointly published by the Office of Design of the Department of Industry, Trade and Commerce, Ottawa, Canada, and the Design Council of Great Britain, London.

Archer, L. Bruce. (1978) Time for a Revolution in Art and Design Education. RCA Papers No. 6. Royal College of Art, London.

Archer, L. Bruce. (1979) Whatever became of Design Methodology? Design Studies 1(1). July 1979. 17-20.

Archer, L. Bruce. (1981a) A view of the nature of design research. In: R Jacques and J Powell (eds.) Design: Science: Method. Guildford, UK: Westbury House/IPC Science and Technology Press. 3047.

Archer, L. Bruce. (1981b) Personal letter from Archer to Prof. George L Smith Jnr, Department of Industrial Systems and Engineering, Ohio State University. L Bruce Archer Archive, Royal College of Art, box 1.3.1.

Archer, L. Bruce. (2004) 'Autobiography of research at the Royal College of Art 1961-1986', notes written for the Rector, Professor Sir Christopher Frayling, at his request in March 2004. L Bruce Archer Archive, Royal College of Art. 
Archer, L. Bruce and J. Beresford-Evans. (1957) Design Analysis 4 - general purpose axe Design 103. July 1957. 20-25.

Ashby, W. Ross. (1957) Introduction to cybernetics. Chapman and Hall.

Bayazit, Nigan. (2004) Investigating Design: A Review of Forty Years of Design Research. Design Issues 20(1). 16-29.

Beer, Stafford. (1959) Cybernetics and management. English Universities Press.

Beresford-Evans J. and L. Bruce Archer. (1957a) Design Analysis 3 - stainless steel cooking pans. Design 102. June 1957. 26-30

Beresford-Evans J. and L. Bruce Archer. (1957b) Design Analysis 5 - free-standing fire. Design 106. October 1957. 52-56.

Bertalanffy, Ludwig von. (1951) General System Theory. Human Biology 23, Dec 1951. 303-361.

Bishop, Terry. (1980) Letter to Bruce Archer. Box 1.8 'Design Council (c.1979-84)'. L Bruce Archer Archive, Royal College of Art.

Boulding, Kenneth E. (1956) General systems theory, skeleton of a science. Management Science. April 1956.

Boyd Davis, Stephen and Gristwood, Simone. (2015) Computing, Design, Art: Reflections on an Innovative Moment in History. In: Preliminary Proceedings of the Third International Conference on the History and Philosophy of Computing (HaPoC 2015), Pisa, Italy, 8-11 Oct 2015. Pisa University Press. 23-25.

Boyd Davis, Stephen and Gristwood, Simone. (2016 - in press) Computing, Design, Art: Reflections on an Innovative Moment in History. In: Proceedings of the Third International Conference on the History and Philosophy of Computing (HaPoC 2015), Pisa, Italy, 8-11 Oct 2015. Springer.

Churchman, C. West. (1961) Prediction and optimal decision. Prentice Hall.

Cotton, Michelle. (2010) Design Research Unit 1942-72. Koenig Books.

Cross, Nigel. (1993) A History of Design Methodology. In M. J. de Vries et aL (eds.), Design Methcdology and Relationships with Science. Kluwer Academic Publishers. 15-27.

Cross, Nigel. (2001) Designerly Ways of Knowing: design discipline versus design science. Design Issues 17(3). 49-55.

Cross, Nigel. (2007) Editorial: Forty Years of Design Research. Design Studies 28(1). 1-4

Dorst, C.H. (Kees). (2003) The problem of design problems. In: E. Edmonds \& N.G. Cross (Eds.), Expertise in Design, Design Thinking Research Symposium 6. Sydney, Australia: Creativity and Cognition Studios Press.

Dreyfuss, Henry. (1959) The Measure of Man: human factors in design. Whitney Library of Design, New York.

Duckworth, Eric. (1962) A Guide to Operational Research. Methuen.

Frayling, Christopher. (2013) Sir Christopher Frayling interviewed by Stephen Boyd Davis at the Royal College of Art, 21 March 2013.

Glanville, Ranulph. (1999) Researching Design and Designing Research. Design Issues 15(2). 80-91.

Granada Television. (1964) Independent Television Programmes for Schools: Design. Summer Term 1964. Granada TV Network, Manchester.

Green, Richard and John Steers. (2006) Design Education-now you see it; now you don't. Position Paper. D\&T Association and NSEAD.

http://www.nsead.org/downloads/Design_Education_position_paper.pdf (accessed 7 November 2015) 
Gristwood, Simone and Boyd Davis, Stephen. (2014) The Reappearing Computer: the past and future of computing in design research. In: Proc. DRS 2014: Design's Big Debates. Biennial conference of the Design Research Society, Umeå, 16-19 June 2014. http://drs2014.org/en/publications/ (accessed 5 November 2015). 618-632.

Jackson, Tanya. (2013) British Rail: The Nation's Railway. The History Press.

Johnson, Jeffrey. (2010) The future of the social sciences and humanities in the science of complex systems. Innovation: The European Journal of Social Science Research 23(2). 115-134.

Jones, John Christopher. (1954) Ergonomics: human data for design. Design 66. June 1954. 13-17. Jones, John Christopher. (1963) A Method of Systematic Design. In: Jones, Christopher J. and D.G. Thornley (eds.) Conference on Design Methods. Pergamon Press, Oxford. 53-73.

Jones, John Christopher. (1966) Design methods compared 1: Strategies. Design 212. 32-35.

Jones, John Christopher. (1969) The State-of-the-art in Design Methods. In: Broadbent, G., \& Ward, A. (Eds.). (1969). Design methods in architecture (No. 6). London: Lund Humphries.

Jones, John Christopher. (1991) Designing Designing. London: Architecture, Design and Technology Press, p.174.

Kirby, Maurice W. (2003) Operational Research in War and Peace: The British Experience from the 1930s to 1970. London: Imperial College Press.

Krippendorff, Klaus. (2008) Designing in Ulm and off Ulm. In: K.-A. Czemper (Ed.), HfG, Ulm; Die Abteilung Produktgestaltung; 39 Rückblicke. Dortmund, Germany: Verlag Dorothea Rohn. 55-72.

Latham, R.L. (1965) Problem analysis by logical approach. Atomic Weapons Research Establishment.

Lawrence, Ghislaine. (2001) Hospital beds by design: a socio-historical account of the 'King's Fund Bed', 1960-1975. PhD thesis of the University of London. Available on the British Library Ethos service, ID: uk.bl.ethos.271734.

National Physical Laboratory. (1956) Wage Accounting by Electronic Computer. Her Majesty's Stationery Office.

Mallen, George. (2011) Interviewed by Jo Stockham and Bronac Ferran at System Simulation Limited, 16 December 2011.

Margolin, Victor. (2010) Design research: Towards a history. In Proc. Design and Complexity - Design Research Society Conference, July 7-9, 2010 at School of Industrial Design, Université de Montréal Montreal, Canada.

Mason, Catherine. (2009) The Fortieth Anniversary of Event One at the Royal College of Art. Proc. EVA 2009, international conference on Electronic Visualisation and the Arts. British Computer Society, London, 6-8 July 2009. 117-128.

McDonough, A. M. (1963) Information economics and management systems. McGraw Hill.

McIntyre, Jean. (1995) The Department of Design Research at the Royal College of Art: its origins and legacy 1959-1988. In: Frayling, C. and Catterall, C. (eds.) Design of the Times: one hundred years of the Royal College of Art. 58-62. Richard Dennis Publications / Royal College of Art.

Pavitt, Jane. (2012) Input-Output: Design Research and Systems Thinking. In: McCarthy, F. (ed.) The Perfect Place to Grow: 175 years of the Royal College of Art. 129-139

Pask, Gordon. (1961) An approach to cybernetics. Hutchinson.

Pessemier, Edgar A. (1966) New product decisions: an analytical approach. McGraw Hill.

Pickering, Andrew. (2002) Cybernetics and the Mangle: Ashby, Beer and Pask. Social Studies of Science 32(3). 413-437.

Rittel, Horst. (1965) Hierarchy or team? In: Richard A. Tybou (ed.) Economics of Research and Development. Ohio State University Press. 174-218 
Rittel, Horst. (1972) On the Planning Crisis: Systems Analysis of the 'First and Second Generations' Bedriftsøkonomen 8. 390-396.

Simon, Herbert A. (1969) The Sciences of the Artificial. MIT Press, Cambridge, Mass.

Tavistock Institute. (1966) Interdependence and uncertainty: digest of a report from the Tavistock Institute. Tavistock Publications. 1966.

Woodham, Jonathan M. (1997) Twentieth Century Design. Oxford University Press, Oxford.

About the Authors:

Stephen Boyd Davis is Professor of Design Research at the RCA, London, where he leads staff research in the School of Design. His research focuses on the representation of knowledge through computation, depiction and diagramming, with an emphasis on chronographics.

Dr Simone Gristwood is Lansdown Research Curator at Middlesex University. Her research focuses on uncovering the histories of the use of computing in the arts and design from the 1960s onwards, primarily through investigating the archives of pioneers. 